\title{
Isolation and Properties of Cytochrome $a$ Deficient Mutants of Bacillus subtilis
}

\author{
By H. TABER \\ Department of Microbiology, University of Rochester School of Medicine \\ and Dentistry, Rochester, New York 14642, U.S.A.
}

(Received 24 September 1973)

\begin{abstract}
SUMMARY
Three classes of cytochrome $a$ deficient mutants of Bacillus subtilis have been isolated. These classes were defined by concentration ratios of cytochromes $a, b$ and $c$ relative to the parent strain, and by responses to non-fermentable substrates. The cytochrome deficiencies were not due to blocks in haem biosynthesis or to failure of the control mechanisms which alter the respiratory chain during growth of $B$. subtilis. Mutational loss of cytochrome $a$ did not reduce proportionately the rate of oxygen consumption by late exponential phase cells, although exponential growth rates were generally lower than the parent strain. The cytochrome system of wild-type $B$. subtilis appears to contain cytochromes $a$ (or $a+a_{3}$ ), $b, c, c_{1}$, and $o$. A previously unreported absorption maximum at $6 \mathrm{I} 7 \mathrm{~nm}$ was discovered, which was elevated in some of the cytochrome $a$ deficient mutants. In these mutants, a new maximum also appeared at $627 \mathrm{~nm}$.
\end{abstract}

\section{INTRODUCTION}

Bacillus subtilis offers certain advantages for the study of genetic and physiological control of respiratory enzymes in bacteria. Several components of the respiratory chain have been identified (Smith, I954; Chaix \& Petit, 1956; Vernon \& Magnum, 1960; Downey, 1964), and B. subtilis cytochromes $c$ and $c_{1}$ have been isolated and studied (Miki \& Okunuki, I969). Mutants with cytochrome deficiencies can be derived by mutagenic treatment (Taber \& Sherman, 1966) and in theory such mutants should be amenable to genetic analysis by transformation (Spizizen, 1958) and transduction (Takahashi, I963). The present report describes the derivation and some properties of cytochrome $a$ deficient mutants in which oxidative metabolism is deranged sufficiently to affect the utilization of non-fermentable substrates, and cause impairment of the sporulation process $(\mathrm{H}$. W. Taber \& E. Freese, unpublished). A recent investigation has revealed grossly abnormal mesosome structures in these cytochrome $a$ deficient strains during the post-exponential growth phase (Freese, 1973).

\section{METHODS}

Bacterial strains. The parent strain, from which all mutants were derived, was Bacillus subtilis $60317(\operatorname{trp} C 2$ ilv $A)$. This strain sporulates at a high frequency and possesses a normal complement of cytochromes.

Growth media and growth measurements. The minimal medium (M) of Spizizen was used (Spizizen, 1958). Glucose or other carbon sources were added to a final concentration of $0.5 \%$. Nutritional requirements were satisfied by the addition of $25 \mu \mathrm{g}$ of the required amino acid $/ \mathrm{ml}$. When solid medium was desired, $\mathrm{I} \cdot 7 \%$ agar (Difco) was added. Nutrient 
sporulation media (NSM) was made according to Fortnagel \& Freese (1968). Tryptose Blood Agar Base (TBAB, Difco) was used for routine culturing of strains. The liquid counterpart to TBAB is called $\mathrm{T}$ medium, and contained $(\mathrm{g} / \mathrm{l})$ : tryptose (Difco), Io; beef extract (Difco), 3; NaCl, 5. When organic acids were used as carbon sources, they were neutralized to $\mathrm{pH} 7 \cdot 0$ with $\mathrm{NaOH}$. For determination of growth in liquid media, 20 to $30 \mathrm{ml}$ in $300 \mathrm{ml}$ nephelometric flasks were aerated well by shaking, and the extinction at $540 \mathrm{~nm}$ measured in a Bausch and Lomb 'Spectronic' colorimeter.

Induction of mutations. Spores of strain 60317 were irradiated for $4 \mathrm{~h}$ in a ${ }^{60} \mathrm{Co}$ source, to about $0.1 \%$ survival. They could then be stored for several months at $4{ }^{\circ} \mathrm{C}$ without appreciable change in mutant frequency.

Detection of cytochrome deficiency. Irradiated spores were diluted to about $10^{3}$ viable, germinable cells $/ \mathrm{ml}$, and $\mathrm{O}^{\circ} \mathrm{I} \mathrm{ml}$ samples plated onto TBAB. After growth overnight at $37^{\circ} \mathrm{C}$, the plates were replica-plated onto TBAB and on the second day the replica was stained with benzidine-hydrogen peroxide reagent (Wu, 1923; Deibel \& Evans, I960), following the procedure (Sherman, 1967) for detecting cytochrome deficiency in yeast. Pale blue colonies were tested for cytochrome deficiency: the corresponding colony on the unstained master plate was transferred to fresh TBAB media for cloning.

The second step was to examine each suspected clone for changes in the visible absorption spectrum. The preparation and examination of cell pastes at liquid nitrogen temperature followed, with minor modifications, the procedure established for yeast (Sherman, 1965; 1967). Cells were grown confluently overnight on TBAB medium, scraped off with a spatula, and the excess liquid removed by air-drying for $5 \mathrm{~min}$ on high-retention filter paper or small squares of Millipore filter material. A few crystals of sodium dithionite were deposited on the cell paste during the drying process. The paste was placed in a cuvette of special design, immersed in liquid nitrogen, then removed and quickly examined in the Hartree microspectroscope (Beck Ltd). Illumination was provided by a $1000 \mathrm{~W}$ projection lamp, and the light intensity controlled with a rheostat. It was found that approximately 20 clones could be examined in an hour by this procedure.

Low-temperature recording spectrophotometry. A Cary model I4 was employed to obtain low-temperature spectral recordings of intact cell pastes. The instrument was equipped with a high-intensity light source and a scattered-transmission accessory. The sample was contained in a cuvette of special design which dipped into a pool of liquid nitrogen contained in an unsilvered Dewar flask. Compensation for scattering by the cell sample was achieved by polyethylene sheeting inserted into the reference beam.

Measurement of extinction ratios. On the spectrophotometric tracings straight baselines were drawn as follows: from $538 \mathrm{~nm}$ to $572 \mathrm{~nm}$, for measurement of absorption due to cytochromes $c(548 \mathrm{~nm}), c_{1}(554 \mathrm{~nm}), o(557 \mathrm{~nm}), b(562 \mathrm{~nm})$; from $572 \mathrm{~nm}$ to $613 \mathrm{~nm}$, for measurement of absorption due to cytochrome $a(602 \mathrm{~nm})$. Vertical lines were drawn from the absorption maxima to these baselines, and the extinction values determined from the heights of these lines.

Oxygen uptake. Rates of respiration were measured at $30^{\circ} \mathrm{C}$ by means of a Clark type oxygen electrode (Yellow Springs Instrument Co.) with a polarizing circuit and waterjacketed cuvette resembling that described by Kielley (I963). Measurements were made in the range 100 to $60 \%$ oxygen saturation. Both intact cells and cell-free preparations could be examined with this equipment. Samples were well aerated immediately before making the determinations. The results are expressed as $\mu \mathrm{mol}$ oxygen consumed/unit time, assuming $237 \mu \mathrm{M}$ to be the saturation concentration of oxygen at $30^{\circ} \mathrm{C}$. 


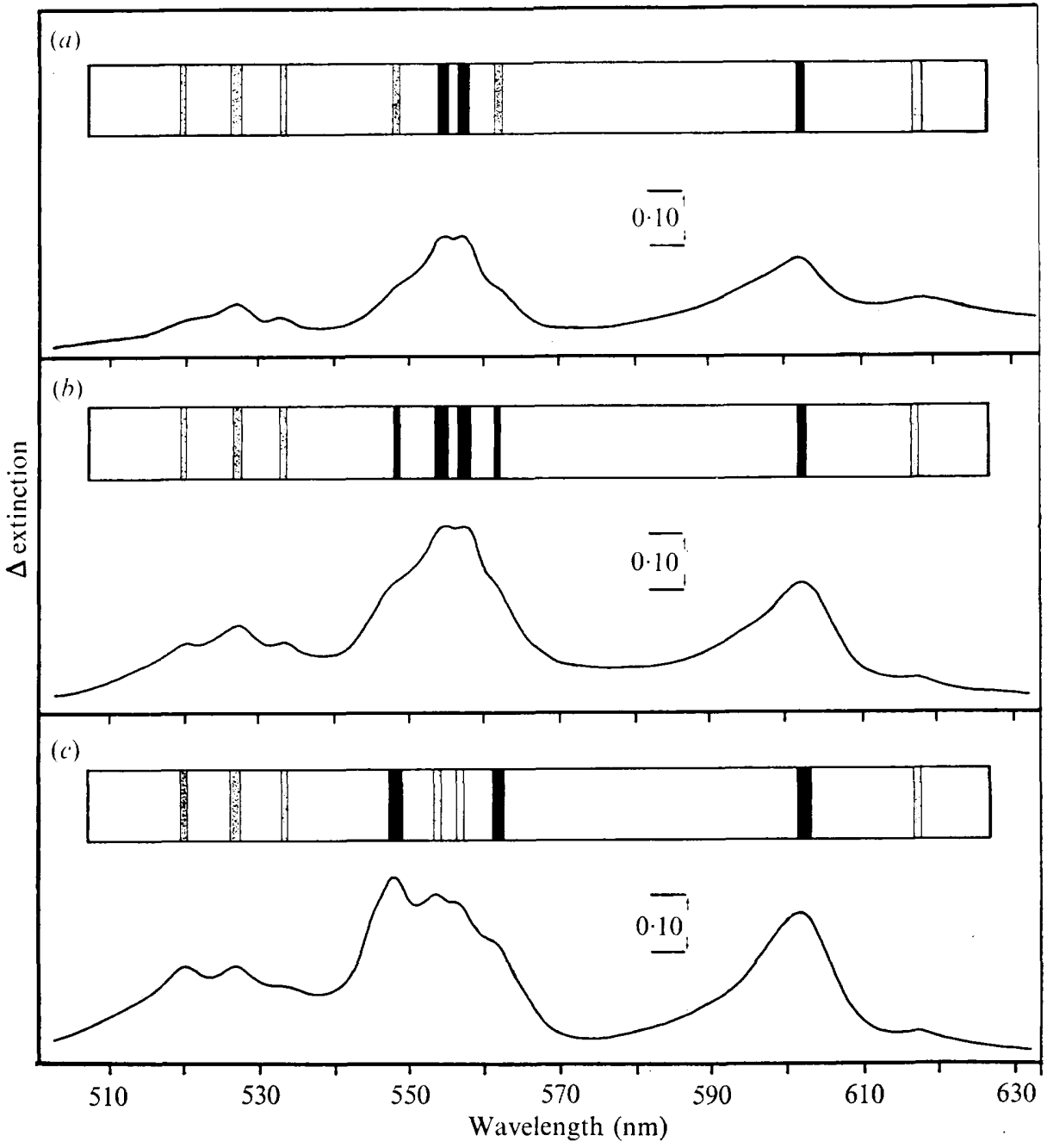

Fig. I. Low-temperature absorption spectra of intact cells of the wild-type B. subtilis strain 603 I 7 . Cultures growing in $\mathrm{T}$ medium were harvested at $T_{-1}(a), T_{0}(b)$ and $T_{3}(c)$.

\section{RESULTS}

Composition of the cytochrome system in Bacillus subtilis

Fig. I shows typical low-temperature visible absorption spectra of wild-type Bacillus subtilis cells harvested at different stages in the culture cycle. Above the spectrophotometric recordings are shown the absorption bands observed spectroscopically. The number, wavelength positions and relative intensities of the $\alpha$-absorption maxima were similar to those previously reported (Chaix \& Petit, 1956) using spectrographic and densitometric techniques for low-temperature recording. By scanning at slow speed, $\alpha$-maxima were identified at $602 \cdot \mathrm{I}, 56 \mathrm{I} \cdot 6$, and $548 \cdot 3 \mathrm{~nm}$, corresponding to cytochromes $a$ (or $a+a_{3}$ ), b and $c$. In addition, the very prominent ' $y$ ' and ' $z$ ' maxima (Chaix \& Petit, I956) were observed at $557 \cdot \mathrm{I}$ and $553.7 \mathrm{~nm}$, respectively. An $\alpha$-maximum at $617 \mathrm{~nm}$, previously unreported in $B$. subtilis, was also present. 
Table I. Cytochrome ratios in the Bacillus subtilis parent strain (60317) as a function of growth phase and medium composition

\begin{tabular}{|c|c|c|c|}
\hline \multirow{2}{*}{$\begin{array}{l}\text { Liquid } \\
\text { growth } \\
\text { medium }\end{array}$} & \multirow[b]{2}{*}{ Growth phase } & \multicolumn{2}{|c|}{ Extinction ratios } \\
\hline & & Cyto $a /$ cyto $b$ & Cyto $c /$ cyto $b$ \\
\hline \multirow[t]{7}{*}{ NSM } & Exponential & & \\
\hline & $\left(T_{-1}\right)$ & $I \cdot 22$ & $1 \cdot 30$ \\
\hline & $T_{0}$ & $1 \cdot 20$ & $I \cdot 30$ \\
\hline & $T_{1}$ & $\mathbf{I} \cdot \mathbf{I} \mathbf{I}$ & $\mathrm{I} \cdot \mathrm{I} 6$ \\
\hline & $T_{2}$ & $1 \cdot 02$ & I.08 \\
\hline & $T_{3}$ & I.06 & $I \cdot I O$ \\
\hline & $T_{4}$ & I 07 & 1.09 \\
\hline \multirow[t]{3}{*}{$\mathbf{T}$} & Exponential & & \\
\hline & $\left(T_{-1}\right)$ & $\mathrm{I} \cdot \mathrm{I} 8$ & $I \cdot I 3$ \\
\hline & $T_{3}$ & $\mathbf{I} \cdot \mathbf{I O}$ & 1.06 \\
\hline
\end{tabular}

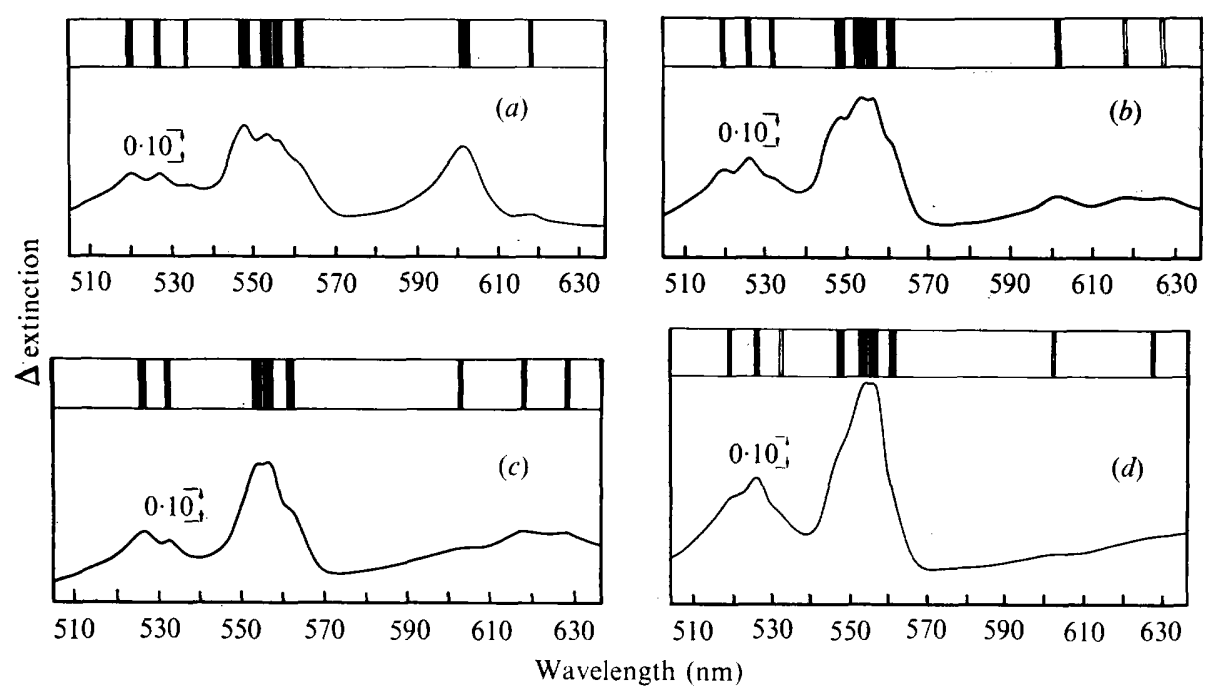

Fig. 2. Low-temperature absorption spectra of intact cells of $B$. subtilis strain 60317 and of cytochrome $a$ deficient mutants derived from it. Cultures growing confluently on TBAB were harvested after $24 \mathrm{~h}$ growth. (a) The parent strain, 60317; (b) strain 60860, a class I mutant; (c) strain 60846, a class II mutant; $(d)$ strain 60862 , a class III mutant.

Cytochrome concentrations during growth. With the aid of low-temperature spectroscopy, Chaix \& Petit (1956) demonstrated that Bacillus subtilis cytochromes underwent concentration changes during the transition from exponential growth to stationary phase growth. Confirmation of their results is illustrated in Fig. I, which shows changes in cytochrome concentrations of wild-type $B$. subtilis growing in $\mathrm{T}$ medium as the culture progresses from mid-exponential phase (Fig. I $a$ ) to $T_{0}$ (the measured end of exponential phase, Fig. I $b$ ), and then into stationary phase $\left(T_{3}, 3 \mathrm{~h}\right.$ after $T_{0}$, Fig. I $\left.c\right)$. We attempted to quantitate these changes by extinction measurements at the $\alpha$-maxima of cytochromes $a(602 \mathrm{~nm}), b(562$ $\mathrm{nm}$ ) and $c(548 \mathrm{~nm})$ (Table $\mathrm{I})$. Although the extinction values varied during growth, extinction ratios remained fairly constant, between $\mathrm{I} \cdot 0$ and $\mathrm{I} \cdot 2$ for cytochrome $a /$ cytochrome $b$, and $\mathrm{I} \cdot 0$ and $\mathrm{I} \cdot 3$ for cytochrome $c /$ cytochrome $b$. Since no mutants lacking cytochrome $b$ were found in this study, the extinction at $562 \mathrm{~nm}$ was taken as a standard against which to measure cytochrome $a$ or cytochrome $c$ deficiency. 
Table 2. Cytochrome ratios of cytochrome a deficient mutants of B. subtilis harvested after $24 h$ growth on $T B A B$

\begin{tabular}{lccc}
\multirow{2}{*}{$\begin{array}{c}\text { Class } \\
\text { Parent strain }\end{array}$} & Strain no. & $\overbrace{\text { Cyto } a / \text { cyto } b}$ & Cyto $c /$ cyto $b$ \\
I & 60317 & $\mathrm{I} \cdot 04$ & $\mathrm{I} \cdot 25$ \\
& & $\mathrm{I} \cdot 06$ & $\mathrm{I} \cdot \mathrm{I} 8$ \\
& 60843 & 0.37 & $\mathrm{I} \cdot 17$ \\
$\mathrm{II}$ & 60860 & 0.50 & 0.93 \\
& $6086 \mathrm{I}$ & 0.32 & $\mathrm{I} \cdot 20$ \\
& 60848 & 0.38 & $\mathrm{I} \cdot 3 \mathrm{I}$ \\
& 60845 & 0.23 & 0.76 \\
& 60846 & 0.26 & 0.60 \\
III & 60863 & 0.30 & 0.48 \\
& 60847 & 0.43 & 0.64 \\
& 60864 & 0.36 & 0.54 \\
& 60844 & 0.14 & $\mathrm{I} \cdot 23$ \\
& 60862 & 0.06 & $1 \cdot 28$
\end{tabular}

\section{Occurrence of mutants}

Approximately 22000 colonies were stained using the benzidine reagent, and 390 poorlystaining colonies were selected for spectroscopic examination. Of these, 82 strains were found to possess deficiencies of various types. Eleven mutants showing cytochrome $a$ deficiency were studied further.

\section{Cytochrome a deficiency}

Spectrophotometric recordings at liquid nitrogen temperature confirmed the cytochrome $a$ deficiencies observed spectroscopically. In contrast to the prominent absorption at $602 \mathrm{~nm}$ in the parent strain (Fig. 2a), the mutants showed very little absorption at this wave length (Fig. $2 b, c, d$ ). Fig. 2 also illustrates the varying degrees to which the concentrations of cytochromes other than cytochrome $a$ were altered. The mutants fell into three classes on the basis of spectral characteristics. Class I mutants (Fig. $2 b$ ) resembled the wild type in the relative concentrations of $b$ - and $c$-type cytochromes absorbing in the 545 to $565 \mathrm{~nm}$ wavelength region, combined with a partial deficiency in cytochrome $a$. The $617 \mathrm{~nm}$ component is present in higher concentrations, and in addition another new absorption maximum occurs at $627 \mathrm{~nm}$. A striking deficiency in cytochrome $a$ is also noted in class II mutants (Fig. 2c) but in this group there is, in addition, a complete lack of cytochrome $c$ (note the absence of the $548 \mathrm{~nm}$ maximum). Class III mutants (Fig. $2 d$ ) were severely deficient in cytochrome $a$, but had approximately normal concentrations of cytochrome $b$ and $c$. The 553.5 and $557 . \mathrm{Inm}$ components, however, were greatly elevated.

In Table 2 are summarized the cyto $a /$ cyto $b$ and cyto $c /$ cyto $b$ ratios for classes I, II and III. These ratios support the qualitative conclusions drawn from Fig. 2. The possible errors inherent in quantitation of low-temperature spectra of intact bacterial cells are illustrated by the cyto $c /$ cyto $b$ ratios of class II mutants. These appeared to range between 38 and $61 \%$ of the parent strain. Presumably this spectrophotometric artifact was a consequence of light scattering by intact cells and not of the split $\alpha$-band of cytochrome $c-554$ (Miki \& Okunuki, I969), since spectroscopic observation of class II mutants showed a complete absence of absorption at $548 \mathrm{~nm}$. 
Table 3. Respiration rates of cytochrome a deficient mutants of $B$. subtilis in nutrient sporulation medium

\begin{tabular}{lccc}
\multicolumn{1}{c}{ Class } & & & $\begin{array}{c}\text { Oxygen } \\
\text { consumption } \\
\left(\mathrm{nmol} \mathrm{O}_{2} /\right.\end{array}$ \\
Panent strain & Strain no. & $E_{625}{ }^{*}$ & 52 \\
I & 60317 & 0.62 & 52 \\
& 60843 & 0.35 & 25 \\
& 60860 & 0.63 & 35 \\
II & 60861 & 0.54 & 32 \\
& 60848 & 0.55 & 54 \\
& 60846 & 0.71 & 36 \\
III & 60863 & 0.28 & 42 \\
& 60847 & 0.44 & 59 \\
& 60864 & 0.54 & 50 \\
& 60844 & 0.31 & 23 \\
& 60862 & 0.24 & 29
\end{tabular}

* The culture was sampled in late exponential growth $\left(T_{-1}\right)$, at the initial maximum of oxygen consumption.

\section{Respiration rates}

Because of the low concentrations of cytochrome $a$ in the mutants, it was anticipated that respiration rates would be correspondingly reduced. However, rates of oxygen consumption in the exponential growth phase did not bear any apparent relationship to cytochrome $a$ concentration (Table 3 ). Even the class III mutants, in which cytochrome $a$ was reduced to a few per cent of normal, consumed oxygen at a rate of about $50 \%$ of the parent strain 60317. It was, however, necessary to rule out an artificial reduction in the respiration rate of the parent strain due to greater growth and consumption of media substrate. Addition of $0.2 \%$ glucose to the culture samples stimulated oxygen uptake by both mutant and parent strain, but the relative respiration rates remained about the same. Thus a marked loss of cytochrome $a$ did not cause the mutants to become proportionately respirationdeficient, at least during the exponential growth phase. In a separate report (Taber \& Freese, 1973), respiration deficiency during sporulation is discussed.

\section{Effects of haem and menaquinone on cytochrome synthesis}

Cytochrome deficiencies must logically occur in haem-dependent mutants of Escherichia coli (Beljanski \& Beljanski, 1957; Săsărman et al. 1968), Staphylococcus aureus (Jensen \& Thofern, 1953; Tien \& White, 1968), and Bacillus subtilis (Anderson \& Ivánovics, I967; Kiss, Berek \& Ivánovics, 1971), when grown without added haem. In those instances where spectral data on the presence or absence of haem proteins was presented, the characteristic cytochrome absorption bands were missing. We have found that the addition of protohaem, haem $a$, or protoporphyrin to growth media did not stimulate growth or cytochrome formation in any of the cytochrome $a$ deficient mutants.

Deficiency in menaquinone (vitamin $\mathrm{K}_{2}$ ) formation by Bacillus subtilis has been shown to depress synthesis of cytochromes $a, b$ and $c$, and to block sporulation (Farrand $\&$ Taber, I97I; $1973 a, b$ ). Addition of quinone biosynthetic precursors will stimulate cytochrome synthesis and restore sporulation in menaquinone deficient mutants. However, addition of shikimic acid or menadione had no effect on the cytochrome concentration of any of the cytochrome $a$ deficient mutants. 


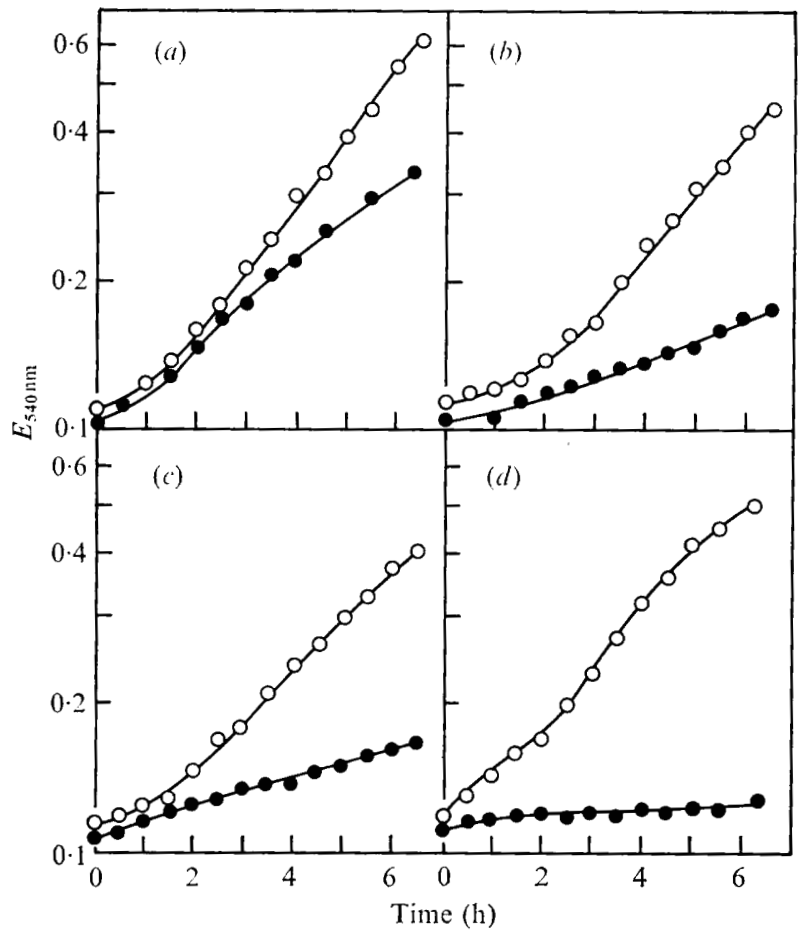

Fig. 3. Growth of representative cytochrome $a$ deficient mutants of $B$. subtilis on minimal medium with glucose or lactate as the carbon source. $(a)$ The parent strain, $60317 ;(b)$ strain 60860 , a class I mutant; $(c)$ strain 60846, a class $I 1$ mutant; $(d)$ strain 60862, a class III mutant. $O$, Growth on glucose; 9 , growth on lactate.

Table 4. Growth rates of cytochrome a deficient mutants of $B$. subtilis on various media

\begin{tabular}{|c|c|c|c|}
\hline \multirow[b]{2}{*}{ Class } & \multirow[b]{2}{*}{ Strain no. } & \multicolumn{2}{|c|}{$\begin{array}{l}\text { Ratio of growth rate } \\
\text { constants* }\end{array}$} \\
\hline & & MG† & Mlctł \\
\hline Parent strain & 60317 & I & I \\
\hline I & $\begin{array}{l}60843 \\
60860\end{array}$ & $\begin{array}{l}0.72 \\
0.68\end{array}$ & $\begin{array}{l}0.25 \\
0.29\end{array}$ \\
\hline II & $\begin{array}{l}60846 \\
60847\end{array}$ & $\begin{array}{l}0.59 \\
0.90\end{array}$ & $\begin{array}{l}0.23 \\
0.31\end{array}$ \\
\hline III & $\begin{array}{l}60844 \\
60862\end{array}$ & $\begin{array}{l}0.8 \mathrm{I} \\
\mathrm{I} \cdot 0\end{array}$ & $\begin{array}{l}<0.05 \S \\
<0.05 \S\end{array}$ \\
\hline
\end{tabular}

* Ratio $=\frac{\text { Growth rate constant (mutant strain) }}{\text { Growth rate constant (parent strain) }}=\frac{\mathbf{I} / \text { doubling time (mutant) }}{\mathrm{I} / \text { doubling time (parent) }}$.

$\dagger$ Minimal medium $+0.5 \%$ glucose.

$\mp$ Minimal medium $+0.5 \%$ sodium lactate.

$\S$ Addition of 28 mm-sodium glutamate had no effect.

\section{Growth characteristics}

The most striking growth property of the cytochrome $a$ deficient mutants was a partial or complete failure to grow on non-fermentable substrates. This is illustrated in Fig. 3 for growth on minimal medium with glucose or with lactate added as carbon source. The 
Table 5. Growth of cytochrome a deficient mutants of B. subtilis on solid media containing non-fermentable carbon sources

\begin{tabular}{|c|c|c|c|c|c|c|c|c|c|c|c|}
\hline \multirow[b]{2}{*}{ Class } & \multirow[b]{2}{*}{ Strain no. } & \multicolumn{5}{|c|}{$\mathbf{M}+$} & \multicolumn{5}{|c|}{$\mathrm{M}+\mathrm{Glu}+$} \\
\hline & & Fum & Mal & Oxa & Let & Gly & Fum & Mal & Oxa & Lct & Gly \\
\hline Parent strain & 60317 & ++ & ++ & ++ & ++ & ++ & ++ & ++ & $+t$ & ++ & $+t$ \\
\hline I & $\begin{array}{l}60843 \\
60860\end{array}$ & $\begin{array}{l}+ \\
+\end{array}$ & $\begin{array}{l}+ \\
+\end{array}$ & $\begin{array}{l}+ \\
+\end{array}$ & $\begin{array}{l}+ \\
+\end{array}$ & $\begin{array}{l}+ \\
+\end{array}$ & $\begin{array}{c}++ \\
+\end{array}$ & $\begin{array}{l}+t \\
+t\end{array}$ & $\begin{array}{l}++ \\
++\end{array}$ & $\begin{array}{l}+ \\
+\end{array}$ & $\begin{array}{l}+ \\
+\end{array}$ \\
\hline II & $\begin{array}{l}60846 \\
60847\end{array}$ & - & - & - & $\begin{array}{l}+ \\
+\end{array}$ & $\begin{array}{l}+ \\
+\end{array}$ & $\begin{array}{l}+ \\
+\end{array}$ & $\begin{array}{l}++ \\
+t\end{array}$ & $\begin{array}{l}++ \\
++\end{array}$ & $\begin{array}{l}+ \\
+\end{array}$ & $\begin{array}{l}+ \\
+\end{array}$ \\
\hline III & $\begin{array}{l}60844 \\
60862\end{array}$ & $\begin{array}{l}- \\
-\end{array}$ & - & $\begin{array}{l}- \\
-\end{array}$ & - & $\begin{array}{l}- \\
-\end{array}$ & $\begin{array}{l}+ \\
+\end{array}$ & $\begin{array}{l}++ \\
+t\end{array}$ & $\begin{array}{l}++ \\
++\end{array}$ & - & - \\
\hline
\end{tabular}

++ , Growth as good as the parent strain $60317 ;+$, much weaker growth than the parent strain; -, no growth. M, minimal salts medium. Fum, sodium fumarate; Glu, sodium L-glutamate; Mal, sodium malate; Oxa, sodium oxalacetate; $28 \mathrm{~mm}$ each. Lct, sodium L-lactate; Gly, glycerol; $0.5 \%$ each.

rates of exponential growth on minimal lactate media were lower for all the mutants than for the parent strain 603I 7 (Table 4). Class I and II mutants grew at 25 to $30 \%$ of the wildtype rate, while class III strains did not grow at all. When tested on solid media (Table 5), class II and class III mutants did not grow on minimal agar to which fumarate, malate, or oxaloacetate had been added as the sole carbon source; class III mutants in addition would not grow on lactate or glycerol. However, when glutamate was added together with any of the three four-carbon acids, growth ensued. It would not, however, stimulate class III mutants on lactate or glycerol (Table 5).

\section{DISCUSSION}

Genetic studies on the cytochrome $a$ deficient mutants have not been presented in Results because these are still at an early stage. However, from preliminary reversion studies it appears that cytochrome deficiency phenotypes, like other pleiotropic negative mutations in Bacillus subtilis (Hoch, I97I) can result from single mutations.

The nature of the altered genes in these mutants is as yet unknown. Investigations with yeast have uncovered a variety of interactions which regulate cytochrome $a$ levels (Ogur, Roshanmanesch \& Ogur, 1965; Reilly \& Sherman, 1965; Sherman, 1965; Sherman, Taber \& Campbell, 1965; Sherman \& Stewart, 1971). It seems probable that haem synthesis is not involved, and that control related to menaquinone synthesis is not impaired.

The studies on growth-dependent variations of cytochrome concentrations in Bacillus subtilis by Chaix \& Petit (1956), and as summarized in Table I, stress the importance of defining the physiological state of a bacterial culture when identification of the cytochrome system constituents is attempted. The 'classical' cytochrome system $(a, b, c)$ can be observed in $B$. subtilis only under very special conditions, namely when the culture is grown on TBAB or other broth agar for 18 to $24 \mathrm{~h}$ without sporulation occurring. Under other conditions the cytochrome system is more complex, containing sizable amounts of the ' $z$ ' $(554 \mathrm{~nm})$ component (Chaix \& Petit, 1956) which appears to be cytochrome $c$-554 (Miki \& Okunuki, 1969).

The studies of Gause (Gause, Kochetkova \& Bibikova, 1964; Gause, 1966) with several species of respiration-deficient bacteria (including Bacillus subtilis) are illustrative of the care which must be taken in distinguishing cytochrome deficiency from failure in physio- 
logical control. We have observed similar 'cytochrome deficiency' during exponential growth of normal strains, and during examination of $s p o A$ and $s p o B$ mutants (Taber, Farrand \& Halfenger, 1972) in which early sporulation blocks prevent the normal elevation of cytochromes $a, b$ and $c$ and the loss of cytochrome $c-554$ and cytochrome $o$.

Although Bacillus subtilis has two terminal oxidases (Tochikubo, 1971) only cytochrome $a$ appears to be related to growth on non-fermentable carbon sources. Fig. 3 and Tables 4 and 5 show patterns of restricted growth by the mutants which seem to correlate roughly with the degree of cytochrome $a$ deficiency. That glutamate metabolism is somehow closely related to the cytochrome deficiencies is suggested by the ability of glutamate to promote growth on four-carbon acids of the TCA cycle, and also by the tendency of several strains to form proline auxotrophs (data not shown).

The genetics of fungal cytochrome systems has progressed rapidly since the early I950s (Mitchell, Mitchell \& Tissières, I953; Slonimski, 1953; King, I97I; Sherman \& Stewart, I97I). Despite the considerable advantages of fungal species for genetic analysis, the relative simplicity of bacterial cells provides excellent material for biochemical investigations of membrane biosynthesis and regulation. Cytochrome mutants of Bacillus subtilis are presently under study with this in mind.

This work was initiated under support by special postdoctoral fellowship 7-F3-CA-I6, 197 while I was a guest worker in the Laboratory of Molecular Biology, National Institute of Neurological Diseases and Stroke, Bethesda, Maryland, U.S.A. The advice and encouragement of Dr Ernst Freese at that time is gratefully acknowledged. Research grant AI 09093 from the National Institute of Allergy and Infectious Disease has supported the later development of this work. I thank Dr Fred Sherman for assisting with the lowtemperature spectral measurements and for many valuable discussions.

\section{REFERENCES}

ANDERSON, T. J. \& IvÁNovics, G. (1967). Isolation and some characteristics of haemin dependent mutants of Bacillus subtilis. Journal of General Microbiology 49, 3I-40.

BELJANSKI, M. \& BELJANSKI, M. (I957). Sur la formation d'enzymes respiratoires chez un mutant d'Escherichia coli streptomycin-résistant et auxotrophe pour l'hémine. Annales de l'Institut Pasteur 92, 396-4I 2.

Chaix, P. \& PetrT, J. F. (1956). Étude des différents spectres cytochromique de Bacillus subtilis. Biochimica et biophysica acta 22, 66-7I.

Derbel, R. H. \& Evans, J. B. (1960). Modified benzidine test for the detection of cytochrome containing respiratory systems in microorganisms. Journal of Bacteriology 79, 356-360.

DownEY, R. J. (1964). Vitamin K-mediated electron transfer in Bacillus subtilis. Journal of Bacteriology 88, 904-9II.

FARRAND, S. K. \& TABER, H. (197I). An aromatic amino acid auxotroph of B. subtilis deficient in cytochromes and in menaquinone. Bacteriological Proceedings, $16 \mathrm{I}$.

FARRAND, S. K. \& TABER, H. (1973a). A pleiotropic menaquinone-deficient mutant of B. subtilis. Journal of Bacteriology II5, I02I-I034.

Farrand, S. K. \& TABer, H. (1973b). Physiological effects of menaquinone deficiency in B. subtilis. Journal of Bacteriology I15, I035-I044.

FortNAGEL, P. \& FreESE, E. (1968). Analysis of sporulation mutants. II. Mutants blocked in the tricarboxylic acid cycle. Journal of Bacteriology 95, $1431-1438$.

FREESE, E. B. (1973). Unusual membranous structures in cytochrome $a$-deficient mutants of $B$. subtilis. Journal of General Microbiology 75, I87-190.

Gause, G. F. (1966). In Microbial Models of Cancer Cells. Amsterdam: North-Holland.

Gause, G. F., Kochetkova, G. V. \& Bibikova, M. V. (1964). Investigation of mutants with oxidation deficiency in B. subtilis. Dokladȳ akademii nauk SSSR I55, II84-1187. 
Hосн, J. A. (1971). Genetic analysis of pleiotropic negative sporulation mutants in Bacillus subtilis. Journal of Bacteriology 105, 896-90I.

JENSEN, J. \& THOFERN, E. (I953). Chlorhämin (Ferriporphyrinchlorid) als Bakterienwuchstoff. Zeitschrift für Naturforschung 8b, 599-607.

KIELLEY, W. W. (1963). Preparation and assay of phosphorylating submitochondrial particles: sonicated mitochondria. In Methods in Enzymology, vol. 6, pp. 272-277. New York: Academic Press.

KING, M. E. (197I). Regulation of cytochrome biosynthesis in some eukaryotes. In Metabolic Regulation, vol. 5 of Metabolic Pathways, pp. 55-58. Edited by H. J. Vogel. New York: Academic Press.

KIss, I., BEREK, I. \& IVÁNOVICS, G. (I97I). Mapping the $\delta$-aminolaevulinic acid synthetase locus in Bacillus subtilis. Journal of General Microbiology 66, I53-159.

MIKI, K. \& OKUNUKI, K. (1969). Cytochromes of Bacillus subtilis. II; III. Purification and spectral properties of cytochromes c-550 and c-554. Journal of Biochemistry 66, 83I-844.

Mitchell, M.'B., Mitchell, H. K. \& Tissières, A. (I953). Mendelian and non-Mendelian factors affecting the cytochrome system of Neurospora crassa. Proceedings of the National Academy of Sciences of the United States of America 39, 606-613.

Ogur, M., Roshanmanesh, A. \& OGUR, S. (1965). Tricarboxylic acid mutants in Saccharomyces: comparison of independently derived mutants. Science, New York 147, 1590.

Reilly, C. \& SHERMAN, F. (1965). Glucose repression of cytochrome $a$ synthesis in cytochrome-deficient mutants of yeast. Biochimica et biophysica acta 95, 640-65I.

Săsărman, A., Surdeanu, M., Szégli, G., Horodniceanu, T., Greceanu, V. \& Demitrescu, A. (I968). Hemin-deficient mutants of E. coli K-I2. Journal of Bacteriology 96, 570-572.

Sherman, F. (1965). The genetic control of the cytochrome system in yeast. In Mechanisms de Regulation des Activities Cellulaires chez les Microorganismes, pp. 465-479. Paris: C.N.R.S.

SHERMAN, F. (1967). The preparation of cytochrome-deficient mutants of yeast. In Methods in Enzymology, vol. Io, pp. 610-6r6. Edited by R. W. Estabrook and M. E. Pullman. New York: Academic Press.

Sherman, F. \& StewART, J. W. (r97I). Genetics and biosynthesis of cytochrome c. Annual Review of Genetics 5, 257-296.

Sherman, F., TAber, H. \& Campbell, W. (1965). Genetic determination of isocytochromes $c$ in yeast. Journal of Molecular Biology 13, $21-39$.

Slonimski, P. (1953). Formations des Enzymes Respirations chez la Levure. Paris: Masson et Cie.

SмITH, L. (1954). Bacterial cytochromes. Difference spectra. Archives of Biochemistry and Biophysics 50, 299-3I4.

SpIzIZEN, J. (1958). Transformation of biochemically deficient strains of Bacillus subtilis by deoxyribonucleate. Proceedings of the National Academy of Sciences of the United States of America 44, 1072-1078.

TABER, H. W., FARRAND, S. K. \& HALFENGER, G. (1972). Genetic regulation of membrane components in B. subtilis. In Spores, vol. 5, pp. I40-147. Edited by H. O. Halvorson, R. S. Hanson and L. L. Campbell. Ann Arbor: American Society for Microbiology.

TABER, H. \& SHERMAN, F. (I966).' Lack of sporulation in cytochrome $a$ deficient mutants of Bacillus subtilis. Bacteriological Proceedings, $3 \mathrm{I}$.

TAKAHASHI, I. (1963). Transducing phages for Bacillus subtilis. Journal of General Microbiology 3I, 2 I 1-2 7 .

TIEN, W. \& WHITE, D. C. (1968). Linear sequential arrangement of genes for the biosynthetic pathway of protoheme in Staphylococcus aureus. Proceedings of the National Academy of Sciences of the United States of America 6r, 1392-I 398.

Tоснікuвo, K. (1971). Changes in terminal respiratory pathways of Bacillus subtilis during germination, outgrowth, and vegetative growth. Journal of Bacteriology ro8, 652-66I.

Vernon, L. P. \& MAGnum, J. H. (1960). Cytochromes of Bacillus megaterium and Bacillus subtilis. Archives of Biochemistry and Biophysics 90, 103-104.

WU, H. (I923). Studies on hemoglobin. III. Ultramicro method for the determination of hemoglobin or peroxidase. Journal of Biochemistry 2, 189-194. 